\title{
The waters were wide: A report on the Art and Science Project "Water/Wai: Mountains to the Sea"
}

\section{THE STORY OF WATER: AQUA VITAE}

The first known Greek/Phonecian philosopher of science, Thales of Miletus, viewed water as both the centre of life and the unifier of nature. We would all still agree - water is essential to life as we know it. Over the millennia, whole civilizations have risen and fallen depending on fresh water security; our species has adapted, thrived, or been decimated, depending on the availability of water. For this reason, water has always been the subject of close governance and stewardship.

In Aotearoa/New Zealand we are blessed with plentiful water and relatively few users, but we are not without conflict over rights to access, such as riparian rights (whereby the right to draw water is shared according to need from the source or flow of the water). Increasing changes in the hydrology cycle caused by climate change will affect water supplies, creating challenges both physical and legal. For these reasons, we must change our game plan and mentality, from that of a short-term pioneering society (seeing water as a "resource that we should fully exploit - before the next person does" ${ }^{\prime 1}$ ), to a long-term stewardship mentality (protecting water as a public good for society and the environment as a whole).

\section{STREAM OF CONSCIOUSNESS}

In 2019, the seventh in the Art and Science Project series ${ }^{2}$ embarked on Art+Water, with the theme of "Water: Mountains to the Sea."

This theme was interpreted in many ways, including: the forms of water, water-related protein structures, ice-formation, water-borne disease in birds, fossilized structures made by aquatic/ marine animals, the impacts of land-use on water quality, water-born environmental DNA, the effects of ocean acidification on marine calcifying organisms, the ecology of coastline shallows and deep ocean canyons, bioengineering on farmland, and conflicts in communities around water scarcity. Several projects involved community-based environmental restoration work, including volunteer projects at the Sinclair Wetlands and at Lake Wanaka. 
As for previous Art and Science projects, the aim of Art+Water was to foster artistic response to scientific research, rather than its illustration. Responses were facilitated by close collaborative work, often between a paired artist and scientist, and supported by monthly communal meetings, where both arts based process and scientific research was shared.

Some participant's projects focused on the molecular, investigating physical and structural aspects of water and its many forms. In an interpretation of a water molecule, Kōpata, Heramaahina Eketone (3) gives a figurative description of tohu as a form of literacy in te ao toi, arising from conversations with Geoff Wyvill. The complexity, simplicity and error in ice crystalization, which Craig Marshall studies in organisms that tolerate freezing, were modeled as the patterns and disruptions of contaminants in ice formation revealed in a knitting pattern for a lace cowl by Stella Lange (4). In Pam McKinlay's Every glacier begins as a snowflake, (5) the crystalline structures of ice, revealed in John Tyndall's historic "ice flower" illustrations, were explored in hand woven panels (as the beginning of a series of works Ice is Cool).

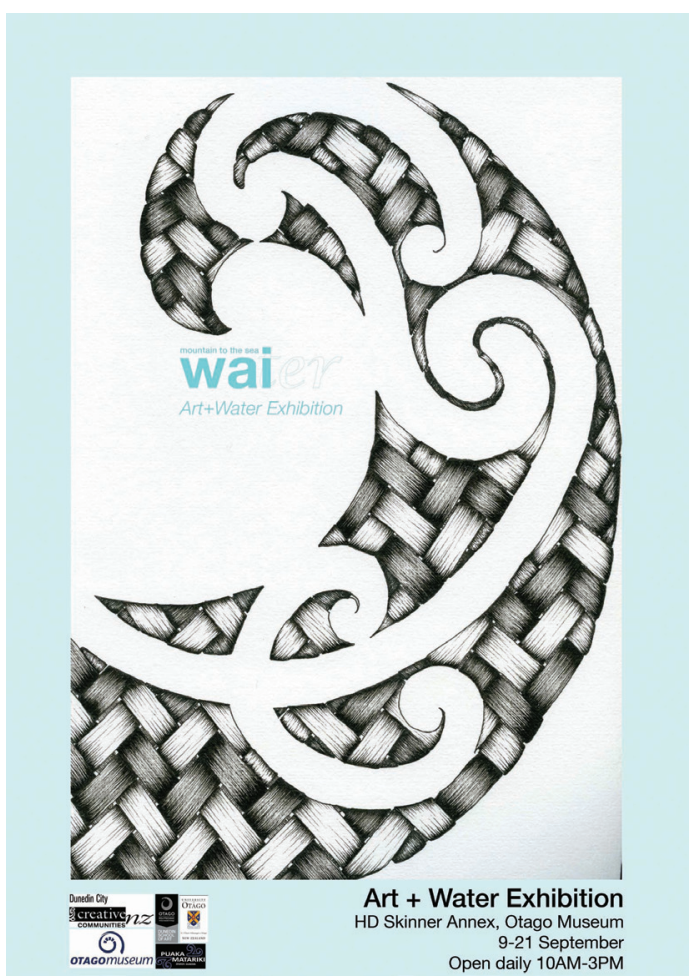

Figure 1. "Art and Wai/Water | Mountains to the Sea" exhibition poster.

(Signature image "Aramoana - pathway to the sea." Drawing by Heramaahina Eketone.

Poster design by Heramaahina Eketone, Joanna Wernham and Pam McKinlay).

Other works examined micrological aspects of aquatic organisms. Clare Adams' research on using minute quantities of environmental DNA shed by animals, such as paua, to monitor diversity in marine ecosystems inspired Kate Elder's 3D-response in hand-painted, layered Perspex to the Haliotis iris DNA barcode (6). Emily Brain invited us to look down through an artistic lens at Plasmodium spp superimposed over her drawing of a yellow eyed penguin (7), which references Jessica Ong's research on avian malaria as an unseen threat to our native sea bird populations. Protein chemists Pauline Uyseco and Sigurd Wilbanks, examining how plants survive flooding on land, study properties of a folding polypeptide (phycoerythrin) in red seaweed (8), which features in the work Stories within Seaweed by Georgina Young (9). She used the red seaweed extract as a natural dye on wool and silk and embroidered a cascade flow at the molecular level, further referencing the role of plants in food sustainability (e.g. cultivated rice terraces). 
Still at sea, in Marine Canyons, Anne Marie Basquin responded to the work of Bryce Peebles, investigating that space where nutrient rich waters allow deep sea life to flourish but where sediment dumping threatens it. Anne also responded to Bryce's research on ocean acidification by delving into local rock pools in search of marine-calcifiers (10). Once again the measure of human activity on these submerged worlds became apparent. What we do on land has flow-on effects, whether in the deep sea or the tidal zone.

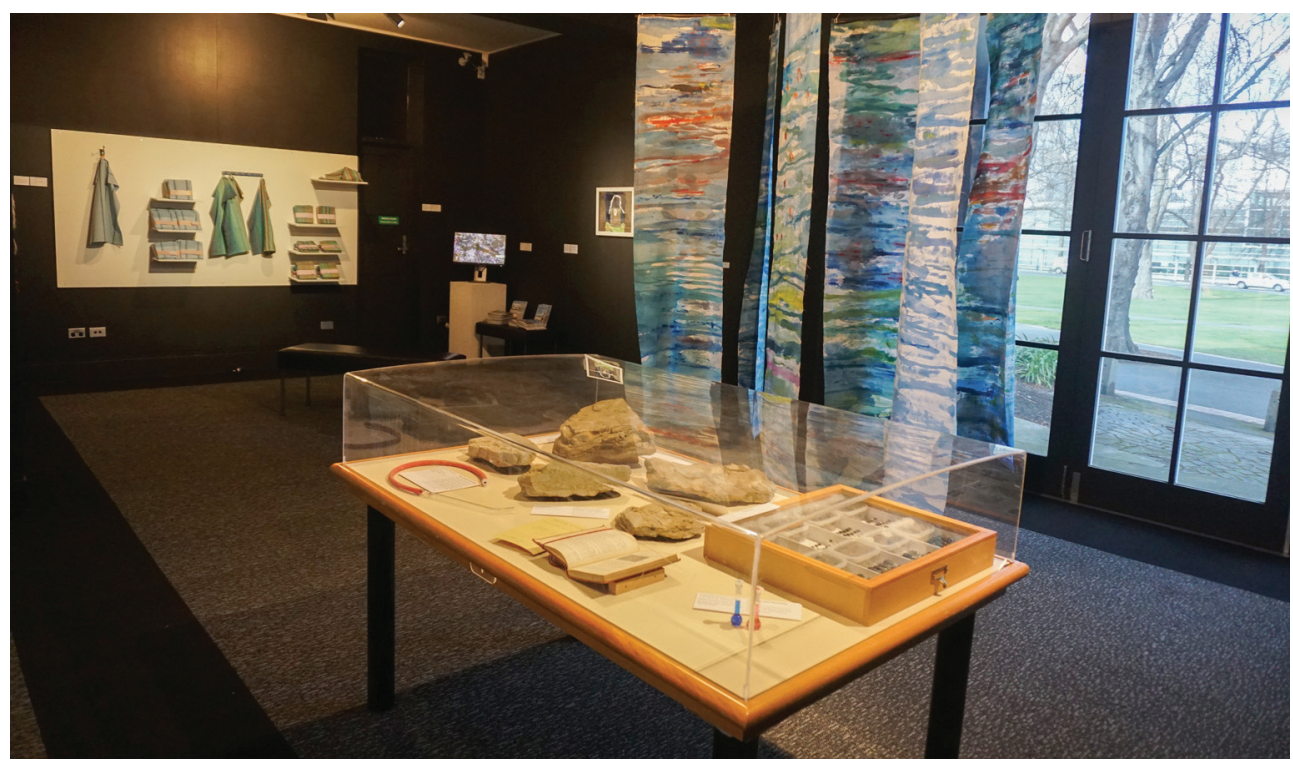

Figure 2. Art+Water Exhibition, Installation view.

Other organisms, both past and present, were the focus of artist-scientist interactions such as that of Jessica Ritchie (11), Emma Curtain, and Henrik Moller in addressing the "new dawn" of dung beetles as bioengineers for cleaning up water ways. The plight of our native galaxiid fish, disappearing from compromised waterways, was revealed in a (literally) moving artwork by guest artist Michelle Wilkinson (12). Creatures that once lived in the fresh water that filled a volcanic crater 23 million years ago are now fossilised in exquisite detail at the Foulden Maar site, where Ruth Evans undertook exploratory watercolors (13) of place and species to reminded us what will be lost if this unique site is mined. Past aquatic life was also explored in the enigmatic trace fossil record of animal activity (e.g. footprints, tracks, and trails), which was the focus of a partnership between scientist Jon Lindqvist (14) and Madison Kelly. Her sculpture, Present and Forthcoming (15), was formed "stratigraphically" from superimposed handmade papers, each bearing a mark of disturbance in each layer that was only hinted at in cross section of the final object.

Although anthropogenic impact was an emergent theme in many works, several focused explicitly on generating engagement between humans and aquatic environments, such as through community-based aquatic conservation and stewardship. Vivien Dwyer's tapestry series, How do you clean water? (16), explored environmental pollution and locals' preventative measures around Lake Wanaka, which is the focus of the citizen science group Touchstone. Annemarie Hope-Cross's 
work, Leave it for the Future (17), was based on interaction with scientist Simone Langhans' fresh water management approach in an Eastern Otago community engagement project. Siau-Jiun Lim's fabric works emerged from her experiences with kaitiaki and coordinator at The Sinclair Wetlands Project (18), Glen Riley, who is working to restore and promote the spiritual, physical, ecological, and cultural value of this wetland taonga. Meanwhile, Sally Carson and her team from the NZ Marine Studies Centre connect the ocean to fresh waters in the hinterland via the "Aquavan." Using hands-on interaction with coastal marine organisms (19), they tell the story of how river health and land management issues impact water catchments all the way to the coast. Weaving her response to their work, Christine Keller (20) explored land-use and source-to-sea connections as part of a tea towel series, Effects of sediment plumes. Christine also worked with Adan Suazo's case studies of community water conflicts over water bottling in both the Rangitata/Ashburton and Glenorchy regions, weaving another tea towel series into our everyday awareness, We have to change.

From the process of molecules folding, to the process of the human collective, the art and science interface provides a fertile medium for us to seek ways to understand the present and find stories by which to engage a wider public with the impacts of our actions. In the productive primordial soup of scientific and artistic processes mixing, we can create new and divergent paths for our future actions.

In the following pages of Part 2 (A Report on the Art+Water project) are extended writings from artists and scientists which capture conversations, research and encounters from within the project.

Pam McKinlay and Jenny Rock

Coordinators Art+Water 2019

Pam McKinlay has been involved with the Art and Science Project for the past six years either as assistant and participant and now as co-coordinator and curator.

Jenny Rock has been involved with the Art and Science Project for several years as co-coordinator and also as researcher, examining its various collaborative effects (on artists, scientists, and the viewing public).

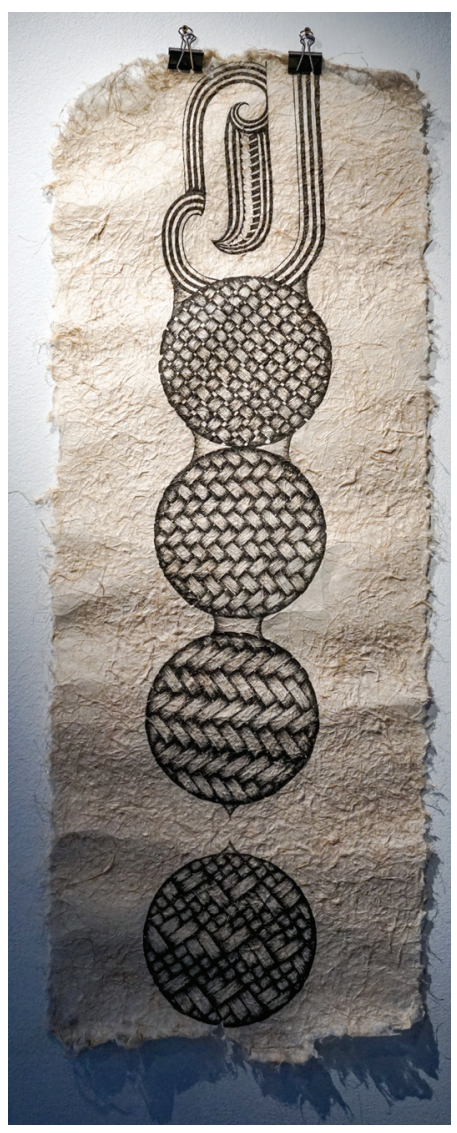

3

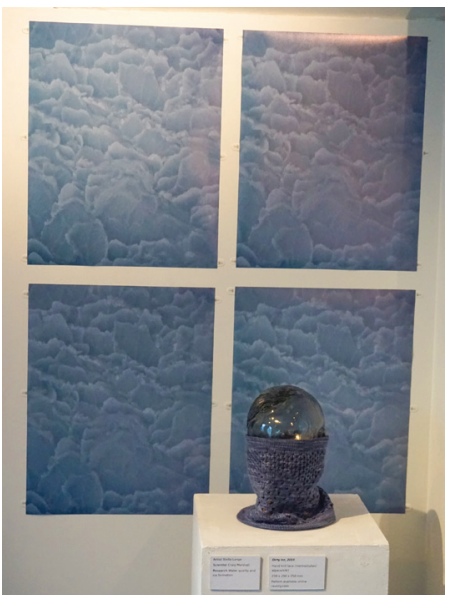

4 
Figures 3 - 20: Exhibition Installation: Art+Water Exhibition 2019.

5
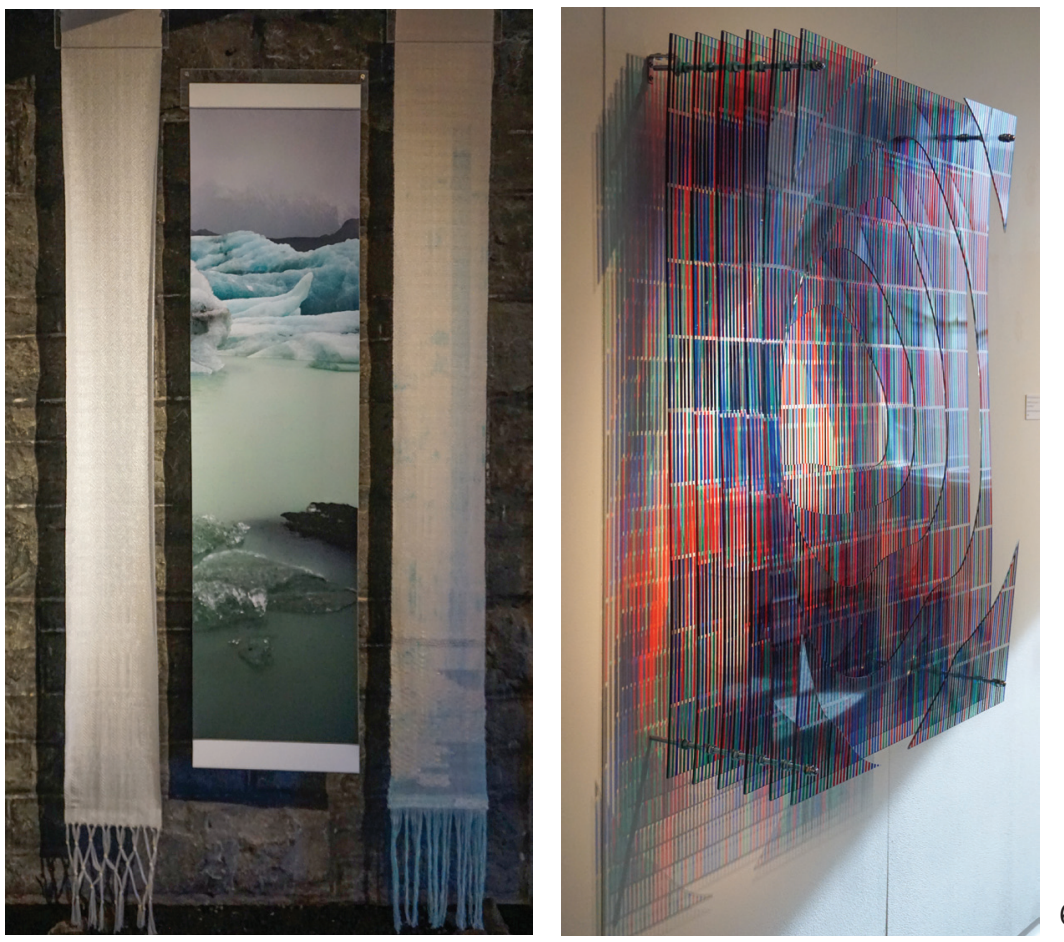

6
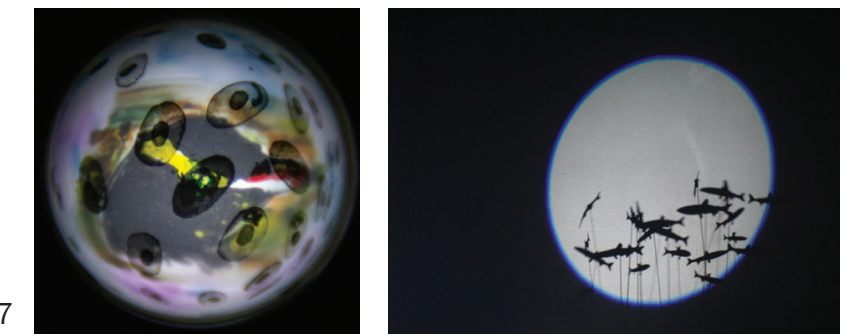

12

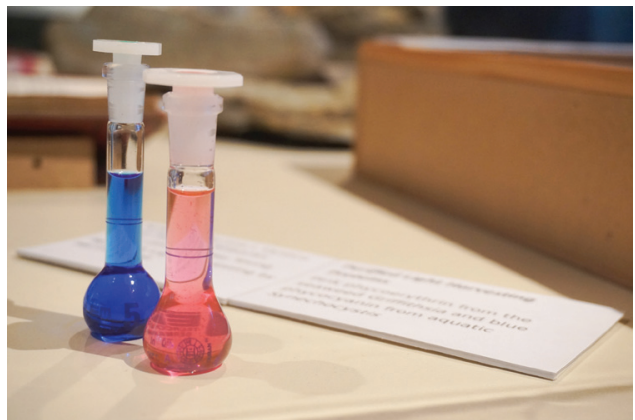

8

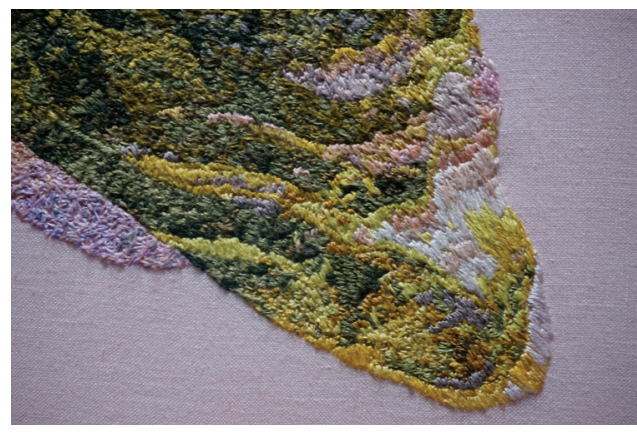



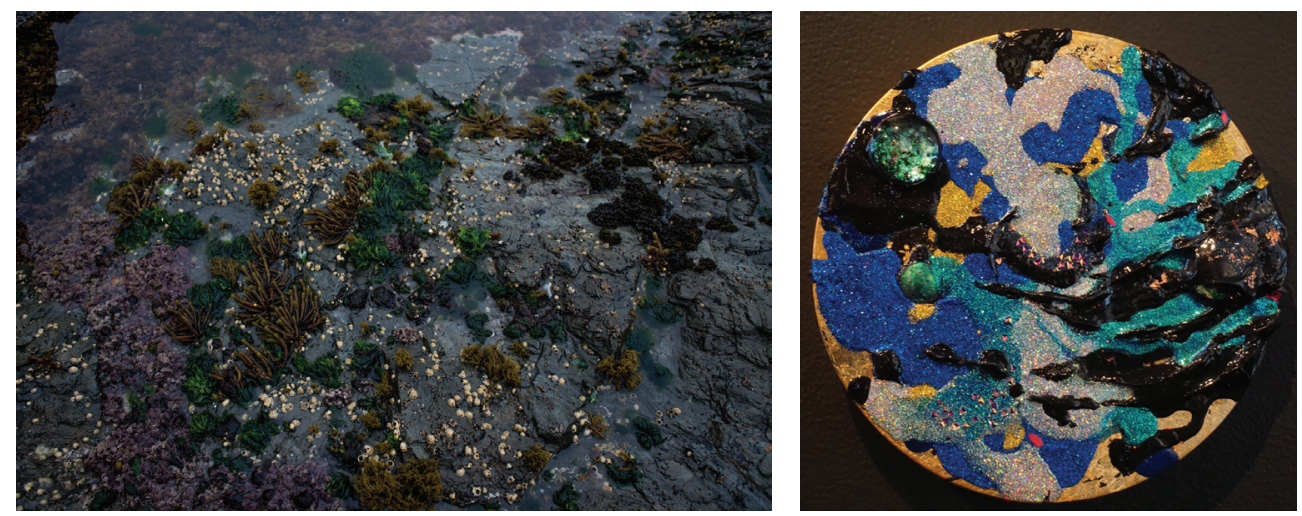

10

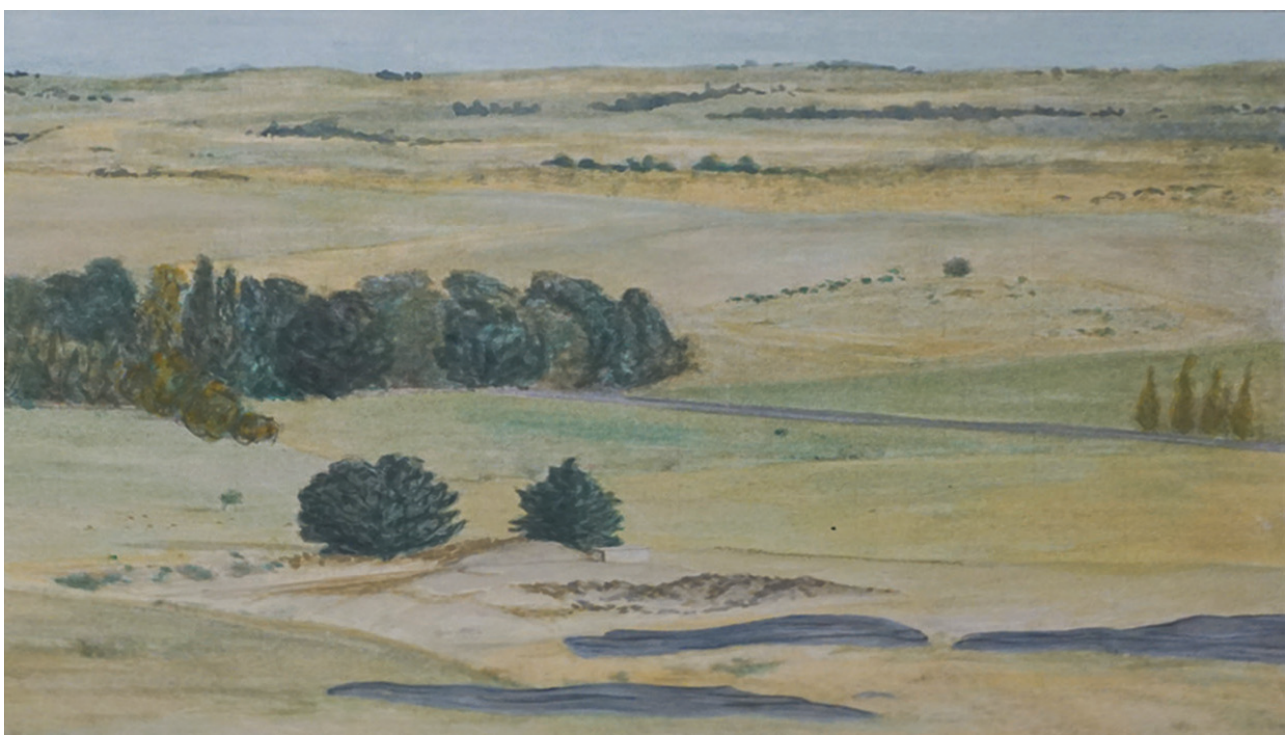

13
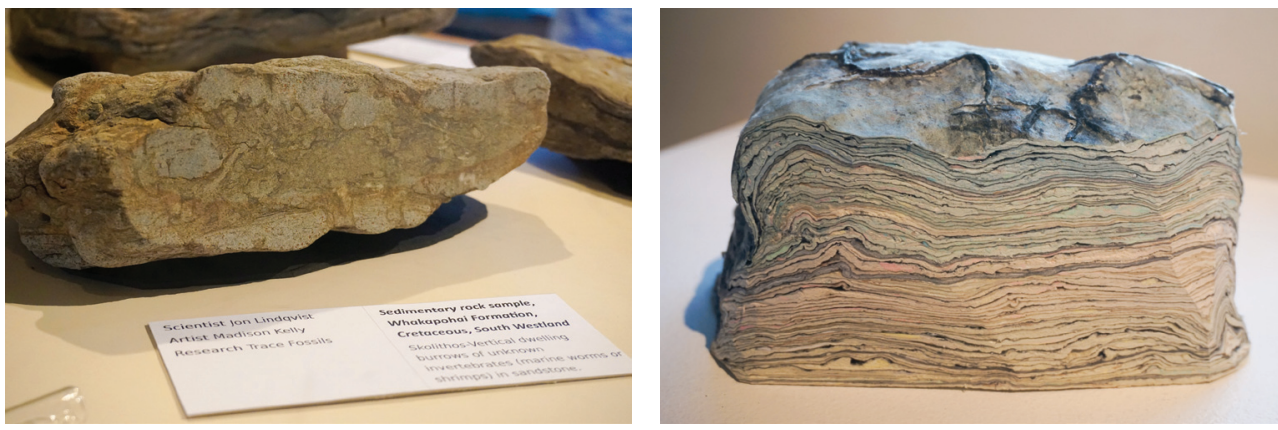

14 


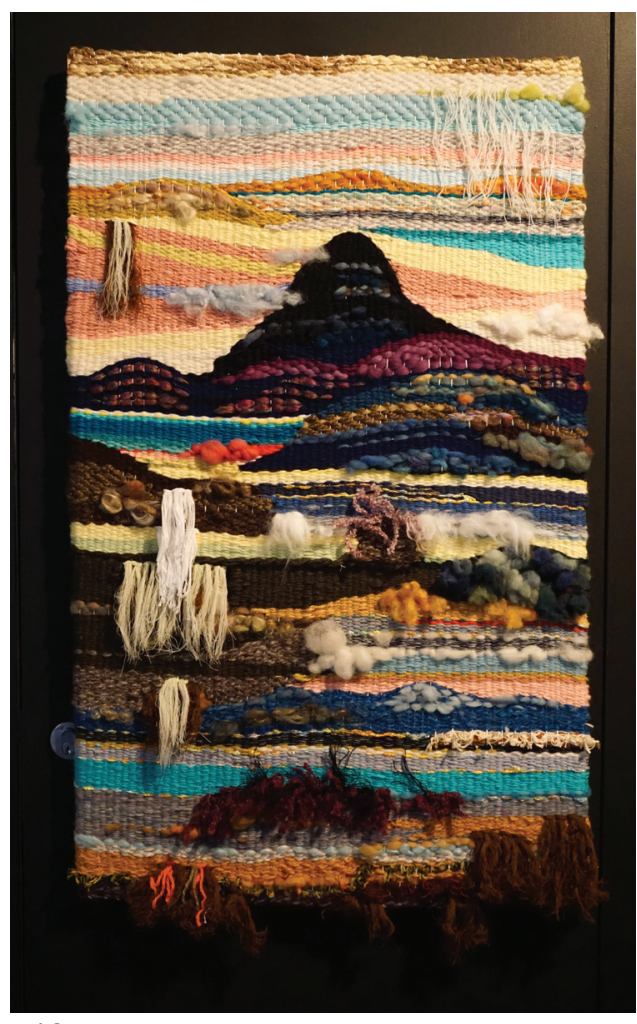

16

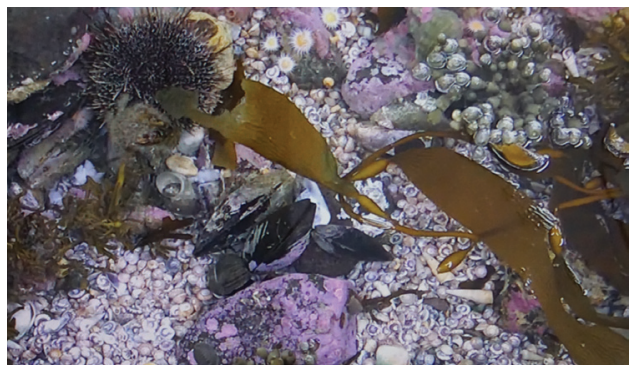

19

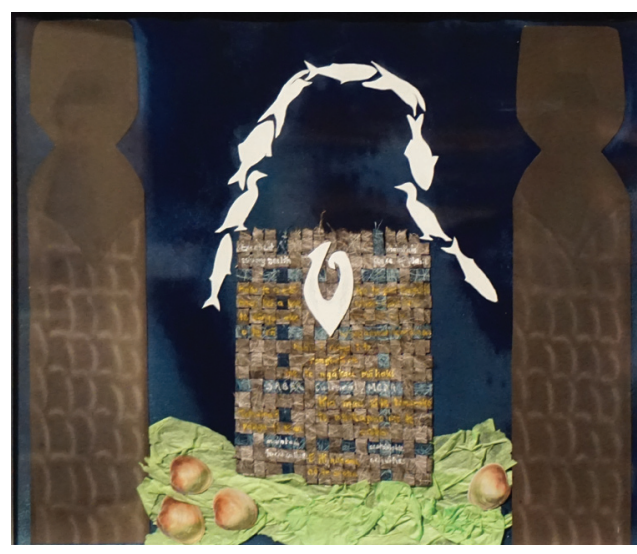

17

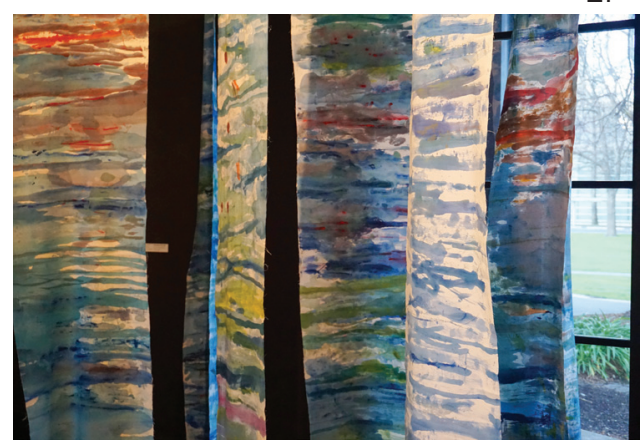

18

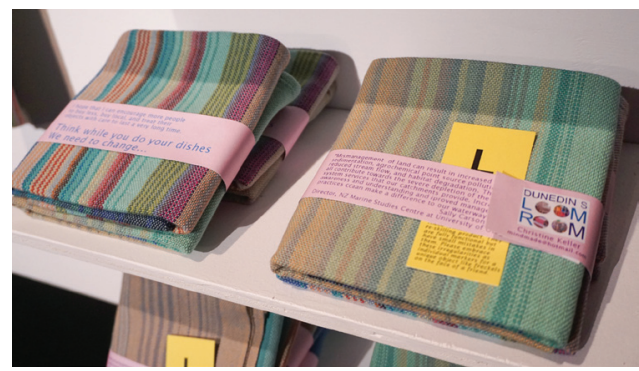

20
1. Catherine Knight, "Are Politics Getting In The Way Of Good Freshwater Governance," Mike Joy (ed.), Mountains to Sea: Solving New Zealand's Freshwater Crisis (Wellington: Bridget Williams Books, 2018), 115.
2. Art and Science Projects archive, https://www. op.ac.nz/study/creative/art/research/projects/ 